\title{
Performance Evaluation Indexes in Public Administration Some issues of their actual usefulness
}

UDK: $35.001 .7: 65.004 .13$

\author{
Laura Tampieri \\ Università degli Studi di Bologna - Facoltà di Economia, Forli, Italia \\ laura.tampieri@poloforli.unibo.it
}

\begin{abstract}
The paper examines the approach to usefulness of performance indicator systems in Public Administration (PA).

There are many international studies about this subject, especially from the point of view of efficiency, effectiveness and adequacy.

The used approach considers the difference among these indicators based on the level of difficulty in PA implementation. The research compares some indicator systems in European Public Administration considering their easiness and feasibility to apply and connecting these qualities to the basic structures of efficiency, effectiveness and adequacy.

The paper aims to compare performance indicator systems of Austria, Italy and Slovenia, emphasizing the relationship between the indicators and their diffusion in government managerial control. In particular the paper underlines the connection between the difficulty of indexes application and the level of diffusion. in Public Administrations.
\end{abstract}

Keywords: performace indicator, perfomance evaluation indexes, efficiency, effectiveness, public administration

\section{Introduction}

Recently, the reform in public sector has placed significant emphasis on policy and program evaluation as a central element of "managing for results" which has became one of public sector milestones (Boyle, 1999).

One of the components in the Italian public administration reform is the buon governo principle related in the administrative action to the criteria of efficiency, effectiveness and adequacy (Farneti, 2002; Pozzoli, 2002).

These criteria have already been expressed in the theories of New Public Management, concerning at first the public operative systems. Governance 
Laura Tampieri

\section{Performance Evaluation Indexes in Public Administration}

has been distinguished from the management decisions and, in a wider sense, the strategy from the management control. Only in this way Public Administration (PA) can apply suitable planning and control instruments.

Traditionally the central and the local governments focused their attention on the problem of administrative legitimacy and formal control, both already adopted in PA. Today, the reform is investigating managerial instruments more strictly related to internal control (Longo, 2004).

The Italian reform is based on a new concept changing the institutional and welfare approach into a managerial one, which underlines the central role of PA in structural and territorial governance (Anselmi, 1998; Mussari, 1998).

Many researches have been done on management control in PA: the control is not considered in a juridical-formal way, it refers rather to managerial economic approach', based on the criteria of efficiency, effectiveness and adequacy (Pavan, 2001; Anselmi, 2003).

In order to allow a deep analysis of public decision-making, the internal control, both management and strategic, requires formulation of results and activities planning with performance indicators (Farneti, 1996).

This process leads PA to change its perspectives from achieving a simple effectiveness to a more complex pursuing of efficiency and adequacy (Morri, 2001), into an integrated control system.

Also in other countries the creation of performance measurement systems in public activities has become a widespread and appreciated evaluation method (Boland, 2000; Cavalluzzo, 2002).

In PA many systems of performance evaluation and management control come from diversified strategies carried on in different countries. In Italy the devolution of central power from the central government to the local government (region, province, municipality) has been thoroughly accomplished, implying a global re-assessment of resources in local areas, in order to define a new role of public activities.

In Italy the interest for performance indicators systems was born in the second half of 1980, when the request of an improved responsibility in public resources management led to focusing the attention on performance and outcomes, expressed in terms of quality, effectiveness, efficiency. Moreover the

1 See D. Lgs 286/1999 “ Riordino e potenziamento dei meccanismi e strumenti di monitoraggio e valutazione dei costi, dei rendimenti e dei risultati dell'attività svolta dalle amministrazioni pubbliche, a norma dell'articolo 11 della legge 15 Marzo 1997, n. 59", Gazzetta Ufficiale n. 193. 
citizens are not considered as submitted to public powers and simple users of public services any instead they have become a strategic factor of managerial success in PA (Mussari, 1998).

The diffusion of performance indicators in executive plans refers not only to local government but also to the other institutions e.g. universities (Vitali, 2001), where those instruments are used to assess and control policies, programmes, projects and teachers performance (Anselmi, 2004).

\section{Performance indexes: effectiveness, efficiency and adequacy}

To address our research in this complex field, we shall start from some definitions and terminological statements, with the aim of reducing the wide variety of assessment instruments and empirical tools developed in different countries and public organizations to evaluate results and performance.

It is important to distinguish between parameters and indexes. Parameters are considered as drivers in performance indicators, referring to objectives, resources and outcomes. For instance, the performance of Public Relations Office can be expressed by the number of information requests expected; the resources by the number of office opening hours for citizens and the outcomes can be calculated as the number of real information accomplished.

The performance indexes are represented by ratios between these parameters. In this way it is necessary to distinguish parameters linked to "time" factor from the others. Time is often a significant resource, useful to control the realized activities and frequently it is the denominator or numerator of many indexes (How much time is used per one piece of product or output or service? How many outcomes, products, services are achieved per time unit?). Moreover, most of plans and projects are measured considering the time factor.

Performance measures can be grouped under a variety of classifications. Some authors (Mayne, 1997) focus on efficiency, quality and effectiveness as performance dimensions.

There are many factors of success or failure, and many different stakeholder groups who put different weight on those dimensions (Connolly, 1980). For example, users might pay most attention to service quality and quantity; staff in public organizations might be more concerned with how a service is provided than with what is provided, and taxpayers are likely to place as much emphasis on cost as on effectiveness. 
Laura Tampieri

\section{Performance Evaluation Indexes in Public Administration}

Some authors (Mayne, 1997) consider that performance monitoring is the easiest when the concentration is on efficiency issues (the relationship between outputs and the inputs used to produce them). The reasons are several, reflecting the fact that quantitative, and hence relatively objective, rather than qualitative, and therefore often more subjective, measures, are the norm. Another reason is that we are usually able to develop performance measures of efficiency rather than having to rely on performance indicators of quality and effectiveness.

Assessment of quality is more problematic. Quality refers to the extent to which the nature of the output and the delivery of the output service meet the organizations' objectives and the users' needs. It is obvious that there is a higher degree of subjectivity involved with quality measures than with efficiency, making a comparative analysis difficult.

Quality can have many shades. The attributes necessary to measure quality might include: accuracy, comprehensiveness, responsiveness, clarity; practicality, appropriateness, fairness, cost-effectiveness. There is a conflicting view between some of those attributes. The solution is to recognize the priority of one attribute over another, depending on the circumstances of the situation.

Effectiveness refers to the extent to which the objectives have been achieved and the relationship between the intended and actual effect of outputs in objectives achievement.

In literature the best known performance indicators are the traditional 3Es (Table 1) of economy (minimizing the consumption of inputs), efficiency (the relationship between inputs and outputs) and effectiveness (outcomes achieved as compared to outputs) (Mayne, 1977).

Table 1: The traditional 3Es performance indicators

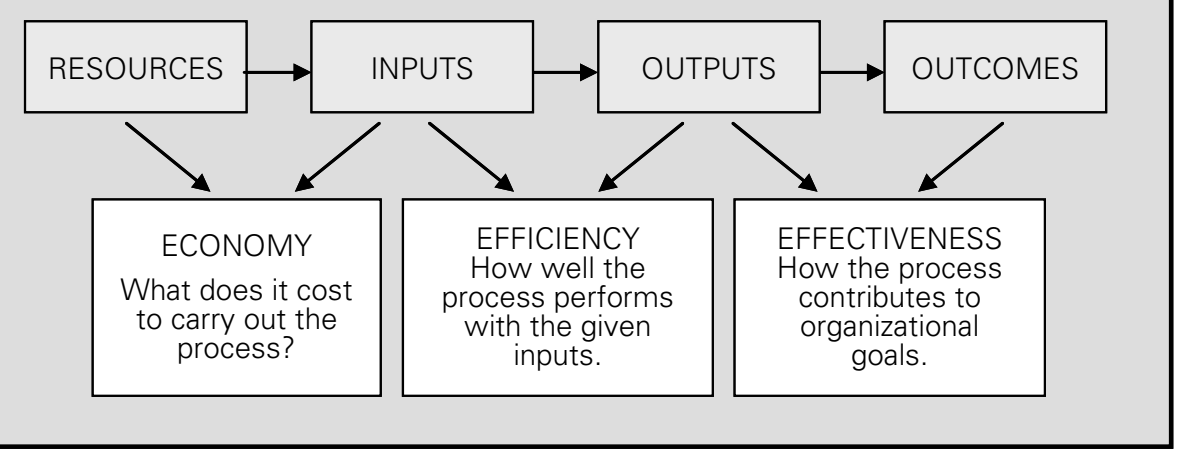


Measures in those three areas reflect the costs of acquiring inputs, the level of outputs achieved with those inputs and the contribution of outputs to produce outcomes. The progression from resources through inputs and outputs to outcomes means that each link has a direct influence on the next, and the three areas of performance measurement concentrate on how these influences operate (OGC, 2002).

Within this indicator system any number of more specialized terms can be defined such as technical vs economic efficiency and administrative vs policy effectiveness (Carter, 1988). To further complicate this picture of indicators authors added several more Es: equity, excellence (Gunn, 1988), as well as effectiveness (Flynn, 1988) and ethics (Jackson, 1988).

For simplicity, the measures are here considered under the categories of effectiveness (Ec), efficiency (Ez) and adequacy (Ad), belonging to objectives, resources and outcome parameters (Bianchi, 2001).

Effectiveness is calculated by outcomes/objectives ratio, such as the relationship between the number of practices produced and those foreseen; this index measures the capacity of an organization, area, sector, service or office to achieve the planned objectives (Harrinvirta, 2000).

Efficiency can be expressed by outcomes/resources ratio, such as the relationship between the number of practices produced and the number of counter opening hours; this index assesses the capacity of an organization, area, sector, service or office to use the available resources in a better way (Boccia 2005). In the same terms productivity expresses the ratio of outputs to the inputs consumed in producing them; inputs express the amount of labour, equipment or other resources used in producing services. The productivity level is determined by measuring outputs, inputs and calculating the ratio (Rosen, 1993).

This group of indexes is completed by adequacy, which is resources/objectives ratio. It compares the consistency of resources to the achievement of planned objectives ${ }^{2}$.

It is useful to place these performance indicators within a wider context, considering the level of difficulty in the application in PA. (Bianchi, 2002).

Through the analysis of these indexes (Bianchi, 2004), developed by different public administrations, we can distinguish four levels of difficulty: easy, quite easy, difficult, very difficult (Table 2).

2 Regarding to indicator system economic doctrines deepened Ec and Ez concepts, while Ad reflections are recent, being linked to supportability (Del Bello A., 2003), feasibility and equity (Grandori A., 1999). 
Laura Tampieri

Performance Evaluation Indexes in Public Administration

Table 2: Indicator classification according to the difficulty of their application

\begin{tabular}{|l|l|l|}
\hline $\begin{array}{c}\text { Level of difficulty in } \\
\text { application }\end{array}$ & \multicolumn{1}{|c|}{ Type } & \multicolumn{1}{c|}{ Example } \\
\hline Easy & $\begin{array}{l}\text { Demographic and } \\
\text { environmental index }\end{array}$ & $\begin{array}{l}\text { Number of students } \\
\text { attending the } \\
\text { school/population }\end{array}$ \\
\hline Quite easy & $\begin{array}{l}\text { Financial index } \\
\text { Budgetary index }\end{array}$ & $\begin{array}{l}\text { Total expenditure on } \\
\text { education }\end{array}$ \\
\hline $\begin{array}{l}\text { Difficult / Quite } \\
\text { Difficult }\end{array}$ & $\begin{array}{l}\text { Performance indexes: } \\
\text { effectiveness / efficiency }\end{array}$ & $\begin{array}{l}\text { Percentage of pupils } \\
\text { passing exams/personnel } \\
\text { expenses per one product }\end{array}$ \\
\hline Very difficult & $\begin{array}{l}\text { Performance indexes: } \\
\text { adequacy, quality, ethics, } \\
\text { rating }\end{array}$ & $\begin{array}{l}\text { Number of disciplinary } \\
\text { sanctions applied/ } \\
\text { personnel }\end{array}$ \\
\hline
\end{tabular}

The table proposes a distinction of indicators according to the difficulty in their application in PA. Demographic and environmental indicators are easier to apply in organizations than the others: statistical indexes refer to parameters such as population and environment. For instance, in a municipality, the facility to obtain data and information through statistical sources allows to create many indicators, such as the relationship between the number of policeman or children attending to primary school and the population.

In the category of quite easy indicators there are financial ones mainly provided by balance-sheet. Nevertheless, those instruments are not very easy to apply because in most cases it is difficult to locate correctly some items of expenditure. In this area we can find the index of financial pressure, which is expressed as the sum of tax and no-tax revenues, divided by population (Reck, 2001).

We ought to emphasize that in public sector the accounting is especially an instrument of inner information and the choice of adequate accounting and control system represents a significant opportunity for public administrations to reach higher level of productivity and quality.

However, financial performance is poor information about how the money has been spent and in what measure citizens expect that public money will be used wisely by public administrations. In this way Eccles (1991), Kaplan and 
Norton (1992) urged organizations to look beyond financial performance indicators. Literature placed particular emphasis on the need to prepare and publish non-financial measures of performance such as customer satisfaction, internal processes of growth and learning indicators. The Balanced Scorecard, developed in the 1990's by Kaplan and Norton, suggests that we view the organization from four perspectives (learning and growth; business process; customer and financial perspective), developing metrics, collecting data and analyzing results.

Moreover to define measures, which express the level of general needs satisfaction, the public administrations should adopt a system that considers indicators of quality, cost and service. They allow controlling the ability of an organization to meet customer requirements, according to the resources expended in managerial process.

Basically there are some problems in applying concepts as efficiency and effectiveness in public administrations, because they regard the performance assessment. In fact, the creation of indicators related to Ez and Ec requires the definition of objectives, outcomes and resources used by an organisation. For instance in education sector of a municipality, effectiveness may be determined as the ratio between the number of satisfied applications for school admission and those forecasted; on the other hand efficiency index may be calculated as the ratio between the service cost and the number of children attending the school. Many difficulties in the concept of adequacy are related to the relationship with concepts of quality and affordability; which are difficult to define in a convenient and synthetic way. In this area we might consider two indicators: one which evaluates if the public administrations are strategically aligned with environment demands. The other index charts the conformity of public administrations choice with ethical principles and the internal well-being of staff local public administration. All those features are linked to evaluation of strategic planning. In a municipality it is very difficult to define the well-being concept because its measure is based on physical aspects, on psychological and management factors.

\section{Performance evaluation indicators in public administration: some international experience}

In Italy, as in other European countries, indicators satisfy two basic informative demands: they can be used by management as instruments of internal control, but also to allow citizens controlling the outcomes produced by public administrations. In such a way citizens, managers and investors can evaluate 
Laura Tampieri

\section{Performance Evaluation Indexes in Public Administration}

public activities and by analysis of indicators achieve a comparison between different local public administrations.

In recent years in Canada the reform of public sector has defined many objectives, such as improving human resource management, enhancing staff training and development, using performance incentives, making government more efficient, improving quality of services, partnerships with organisations/agencies outside central government, management of finance, more effective managing in PA.

In the performance-based management the public sector managers need to balance the demand for better service with progressively reduced resources.

To meet this demand, it was recognised that managers must be provided with tools to measure the on-going performance of programmes and to apply that information to produce the needed changes in program delivery (OECD, 1994).

Public service managers ought to receive clear and precise information on how well their programmes perform. They need to know how well they operate, how well they serve the needs of their clients, how well they achieve their goals and how cost-effective they are. In short they need to know if they are providing a high - quality service that achieves the wanted results and gives real value for the cost.

In Canada, the government elaborates an annual report ${ }^{\mathbf{3}}$, which shows the data and statistical indicators regarding economical and social fields in PA (for example the ratio between the number of students and the population). These indicators are easy to apply in PA, but they do not allow to realize a deep control of public activities; they are used to give some useful details about statistical parameters, which are often components of many indicators (such as effectiveness, efficiency, economical-financial indexes).

Some initiatives of performance measurement have been developed and used by Canadian public administrations, to support work planning and internal resource allocation. Thus different types of measures are used, but service quality, efficiency and financial measures are the most common. The emphasis on formal measurement system had characterized Canadian system until some years ago when a steady movement towards a results-based culture was developed: performance can be measured in terms of what is being delivered (outputs or activities), or in terms of the actual impact of the activity on individuals (OECD, 1997).

3 Report Canada's Performance 2003 made by Treasury Board of Canada Secretariat. 
As regards U.K., the idea that public services can be produced more efficiently has been widespread since the expansion of the modern state in the early twentieth century. For over a century, local authorities in U.K. focused their attention on revenues and expenditures. In 1980, with the Local Government Planning and Land Act, central government required local administrations to publish an annual report on their performance. However the government's code of practice on the content of such reports concentrated on financial information. In fact, few indicators of output or outcomes have been developed by local authorities (Boyne 2002).

In 1992, the Local Government Act imposed the Audit Commission to determine indicators of efficiency and effectiveness. In this way it was possible to compare performance indicators of many public administrations (Sanderson, 2001).

A striking feature of UK public services in 1990s was the increase of performance monitoring; it was introduced by government in an attempt to measure the processes and outcomes of the public services, and as a goal to efficiency and effectiveness. This was related to: a) increased capacity to record aspects of the public services, brought about by developments in information technology; b) demands for increased accountability both of public services and professionals; c) extensive use of explicit contracts for the provision of public services; d) pressure to ensure that public finances are spent efficiently. During the 1990 s most indicators refer to the quality and quantity of service output, such as the number of playground areas or the percentage of housing repair appointments made and kept; effectiveness was considered as the percentage of unfit dwellings made fit or demolished. On the contrary the criterion of responsiveness has been entirely ignored (Andrews, 2003).

In order to improve the assessment of the public administration performance, a new Best Value Regime was introduced, involving more indicators of quality, outcomes and responsiveness, putting citizens at the centre of public service provision. For instance, considering library in public administration, the costumer satisfaction is measured as the percentage of library users with staff or opening hours; while the citizen satisfaction is calculated as the percentage of citizens with the overall service provided by their authority ${ }^{4}$.

The implementation was partly achieved by stripping out many indicators of expenditure and non-comparable aspects of performance and partly by the addition of new measures of service outcomes, responsiveness, and

4 Audit Commission (1995), Local Authority performance indicators, 1993/1994 (HMSO, London). Audit Commission has an important role in promoting the use of performance information to drive improvements in public services. It works with government departments, national agencies and local authorities to agree and define a wide range of local performance indicators. 
Laura Tampieri

\section{Performance Evaluation Indexes in Public Administration}

democratic outcomes. However the absence of indicators linked to costs with service outcomes has been a considerable weakness.

The idea that public organizations are inherently and massively inefficient, is linked to the trio of public choice reforms (more competition, smaller organisations, more performance information), which is intended to reduce, if not remove, the supposed existence of the monopoly power of public officials.

Economists usually distinguish between two concepts of efficiency (Jackson, 1988):

- Technical efficiency as the ratio of service inputs (e.g. spending) to outputs, which are the goods or services actually produced by an organization (e.g. new houses built, teaching provided in schools);

- Allocative efficiency as the match between such outputs and the preferences of the public (e.g. whether the houses built meet the needs of families who lack suitable accommodation, whether the teaching reflects the demands of parents and pupils).

The second definition of efficiency overlaps closely with the concept of responsiveness as used by public choice theorists. The concept of efficiency will, therefore, be interpreted in this paper in its technical sense.

Moreover this meaning of the term has become familiar to policy-makers and managers in discussion about the 3Es of economy, efficiency and effectiveness (Tomkins, 1987). Measures of technical efficiency usually focus on unit costs, which can be interpreted simply as the financial resources required to create a unit of service provision.

The growth of the welfare state was intended to remedy a lack of responsiveness in private systems of service production and allocation.

In order to evaluate whether public organizations have led to more or less responsiveness, it is necessary to address two main questions. First in what respects should public services be responsive? High responsiveness implies that members of public are happy with public services - but happy with which aspects of them? It would be possible to take customer satisfaction as a proxy for responsiveness, but satisfaction with what? Second to whom should public officials be responsive when making decisions about the design and delivery of services? The public can be divided into a variety of stakeholders. Should all of these potential stakeholders be given equal weight? (Boyne, 2003).

In UK, the activities and achievements of public administrations can be divided into a variety of categories. These typically fall into three broad domains: input to services (such as expenditure, staffing and equipment); outputs of services (such as quantity and quality, which in turn can be divided into the speed and accessibility of service delivery), and outcomes which relate to 
whether formal objectives are achieved (e.g. whether school pupils pass exams). Furthermore, some of the activities and achievements can be combined to form important ratios (efficiency is the ratio of outputs to inputs, and costeffectiveness is the ratio of outcomes to inputs, otherwise known as value for money).

Public choice theorists have emphasized responsiveness to public demands concerning a restricted subset of these dimensions of organizational performance. In particular the Audit Commission defined five performance criteria: outputs, efficiency, service outcomes (equity and cost per unit of service outcome), responsiveness (citizen satisfaction) and democratic outcomes (participation and accountability) and fifteen sub-domains in order to measure and assess the performance of both specific services and local government as a whole (Boyne, 2002).

Local governments have focused narrowly on expenditure inputs and technical efficiency. The obsession with the financial aspects of responsiveness is based on their belief that the public sector is bloated, spendthrift and profligate in its use of resources: public services, actually, have to be done within a defined time limit.

In Germany, after the introduction of New Management System, public activities are mainly oriented to outputs (objectives and outcomes) rather than inputs. The control is realized by a systematic comparison of tasks to be solved (purpose, results), checking costs and reporting activity. In this way the control system is not purely monetary but it is aimed also towards the organisational change (Peess, 2001).

Instead of a bureaucratic control process, focused on the implementation of rules and operating procedures, the control system is intended as a sort of organisation based on the orientation towards the needs of citizens considered as customers and employees.

In this context, government supported the implementation of all the instruments of New Public Administration Management System, such as the creation of indicators system in order to control and evaluate administrative activities. Through the system of indicators it is possible to quantify the resource applications, performance and their impacts. German public administrations pay attention mostly to the indicators of efficiency, which evaluate the capacity of using human, financial and instrumental resources, in order to achieve results. The traditional accounting system, governed by national laws, aims to observe expenditure authorizations and public revenue pattern and so it is unable to provide data about management economic development (Luder, 1988). 


\section{Laura Tampieri \\ Performance Evaluation Indexes in Public Administration}

In this way many useful indicators can be created, such as the rate of costs covering or personnel expenses per one service unit or service/product. They provide improvement in public administrations but there are many operating difficulties to implement an economic accounting system (Farneti, 2005).

In 2000, in order to face the growth of public expenditure, the Austrian administrations carried out a plan ${ }^{\mathbf{5}}$ of cutting down the expenses and supplying quality service to citizens. This program demanded the consideration of many actions such as: the introduction of quality management, the benchmarking activity with other institutions, the development of efficiency indexes, the simplification of administrative procedures and the support of technology (internet) in the informative process among public administrations and with citizens (Scherrer, 2004) ${ }^{\mathbf{6}}$.

Also in this case the reform was based on changing the orientation of administrative action from input to output. The new process required cost and service transparency and an accounting focused on resources. To this purpose there is a growing use of effectiveness and efficiency indexes. In order to achieve useful information on the improvement of public sector, the Austrian government supports international comparison with other countries (International Benchmarking Network of the Public Management Service).

A real systemic approach has been demonstrated in the Republic of Slovenia by Ljubljana University project ${ }^{\mathbf{7}}$, with the support of the Ministries of Interior and Finance. The project realized a performance indicator system, accessible on internet (www.fu.uni-lj.si/sib/vhod-ang.htm). The indicators used in order to compare and evaluate the Slovenian municipalities performance are very simple and understandable (Devjak, Peček, 2001).

With the intention to inform citizens about the performance of 193 Slovenian municipalities, the project proposes a set of three groups of 75 performance indicators: 5 synthetic indicators (such as the level of municipality's financial independence), 17 indicators of budget revenues (as the ratio

\footnotetext{
5 http: www.oecd.org "Issues and developments in public management: Austria 2000". 6 Sherrer (2004) distinguishes between "hard" location factors and "soft" factors. The first factors consider local markets, infrastructure, geographic position and public finance. Each of these factors includes four dimensions (quantity, quality, cost/price, and risk involved) which can be expressed by quantificable indicators. Soft factors include politics, administrative and legal system, and quality of life. These indicators generally are more complex, because they are mainly qualitative by nature, and therefore they are difficult to quantify. Recently Public Administration mainly used so called "hard indicators", such as resources and outputs to control performance; increased attention on accountability and issues around impacts and outcomes have stimulated the introduction of "soft" indicators (citizens and users satisfaction targets). Moreover there is increased demand for information on performance in relation to governance as a whole, including "quality of life" indicators, that are difficult to quantify (Bouckaert; Van de Walle 2003).

7 http://www.fu.uni-lj.si. Faculty of Administration - University of Ljubljana.
} 
between the current revenues and population) and 53 indicators of budget expenditure (as the ratio between the expenditure regarding the environmental protection and the population). All the data are represented as an absolute number as well as calculated per inhabitant.

Performance indicators are budgetary items and they are contained in the annual report sent by municipalities to Ministry of Finance. The creation of these indicators is a simple process owing to its link with demographic and social parameters, such as number of students, $\mathrm{km}$ of roads, etc. Most data have been provided from the national statistical office.

In Slovenia Public Administration has a significant role in government policies and the quality of public choices and their actual social value depend on the effectiveness and efficiency of its action. In addition, one of public administration targets is wider access of internal and external public to operating and strategic information.

According to this, indicators system has two purposes: citizens can check the actions of municipal administrations and municipalities realize performance comparisons and achieve useful information to improve results.

In Netherlands significant management reforms have been introduced changing the way in which public sector operates. However, it is important to ensure that gains in efficiency and effectiveness should not reduce the level of ethical conduct. Reforms involving decentralization to organizations at subnational level, devolution of responsibility and wider managerial autonomy, have increased commercialisation of the public sector and a public/private relationship system and frequently create conflict situations of interest or objectives.

The Netherlands administration requires the use of performance measures in annual report and financial statements. Performance measures have until recently focused more on input and activity indicators than on efficiency and effectiveness (OECD,1997). In addition, international initiatives have concentrated on the development of concrete elements in ethics (such as codes of conduct), mainly to prevent or sanction certain forms of illegal behaviour, such as corruption. In this way increased regulation and law enforcement were the first responses to misconduct in the public sector.

In recent years there has been a considerable increase concerning importance of integrity in public administration in Netherlands. Integrity is a sine qua non for proper functioning of public administration, due to several general trends such as the changing role of government (public and private interests are becoming joined) and the increasing complexity of legislation (Maas, 1995). 
Laura Tampieri

Performance Evaluation Indexes in Public Administration

In Netherlands, at the beginning of 1995, the Ministry of the Interior requested all ministries to develop a policy, with the purpose to support and to improve the system of ethical values at the base of each PA. This system of indicators, referring to ethical aspects in organizations, is oriented to a systematic control of personnel recruitment and selection, to the drafting of conduct rules for public servants, to the imposition of disciplinary sanctions and the analysis of internal organizational structure. The ethical indicators can be expressed by the relationship between the number of disciplinary sanctions applied in a year or from the number of ethical code violations both related to staff dimensions.

In order to promote the culture of human resources, the development and the respect of an ethical conduct, public administrations organize internal and external training courses.

\section{Relationship between performance indicators and their diffusion in government managerial control: a comparison among Austria, Italy and Slovenia}

Let us deepen the analysis of performance system indexes (effectiveness, efficiency and adequacy) by comparison of the indicators in Austria, Italy and Slovenia.

We have compared the performance indexes, chosen among the key indicators on European policy published by Eurostat*. The aim is to link performance indicators with their diffusion in PA. In this way we have tried to identify the usefulness of the indexes proposed by Eurostat (Table 3).

The above table distinguishes three performance indicators: effectiveness, efficiency and adequacy. While the indicators referring to effectiveness are very diffused in order to assess public activities because they are the ratio outcome/objective, efficiency indicators can be expressed by the ratio outcomes/resources and its diffusion level can be considered medium. Another performance indicator is adequacy, which is less diffused because of its deep relationship with complex and undefined concepts of quality, ethics (Table 4).

\footnotetext{
* Eurostat's mission is to provide the European Union with a high-quality statistical information service. Eurostat is not the only source of rating; numerous other sources of indexes from public institutions and private companies exist.
} 
Laura Tampieri

Performance Evaluation Indexes in Public Administration

Table 3: Comparison of performance indicator systems in Slovenia, Austria and Italy

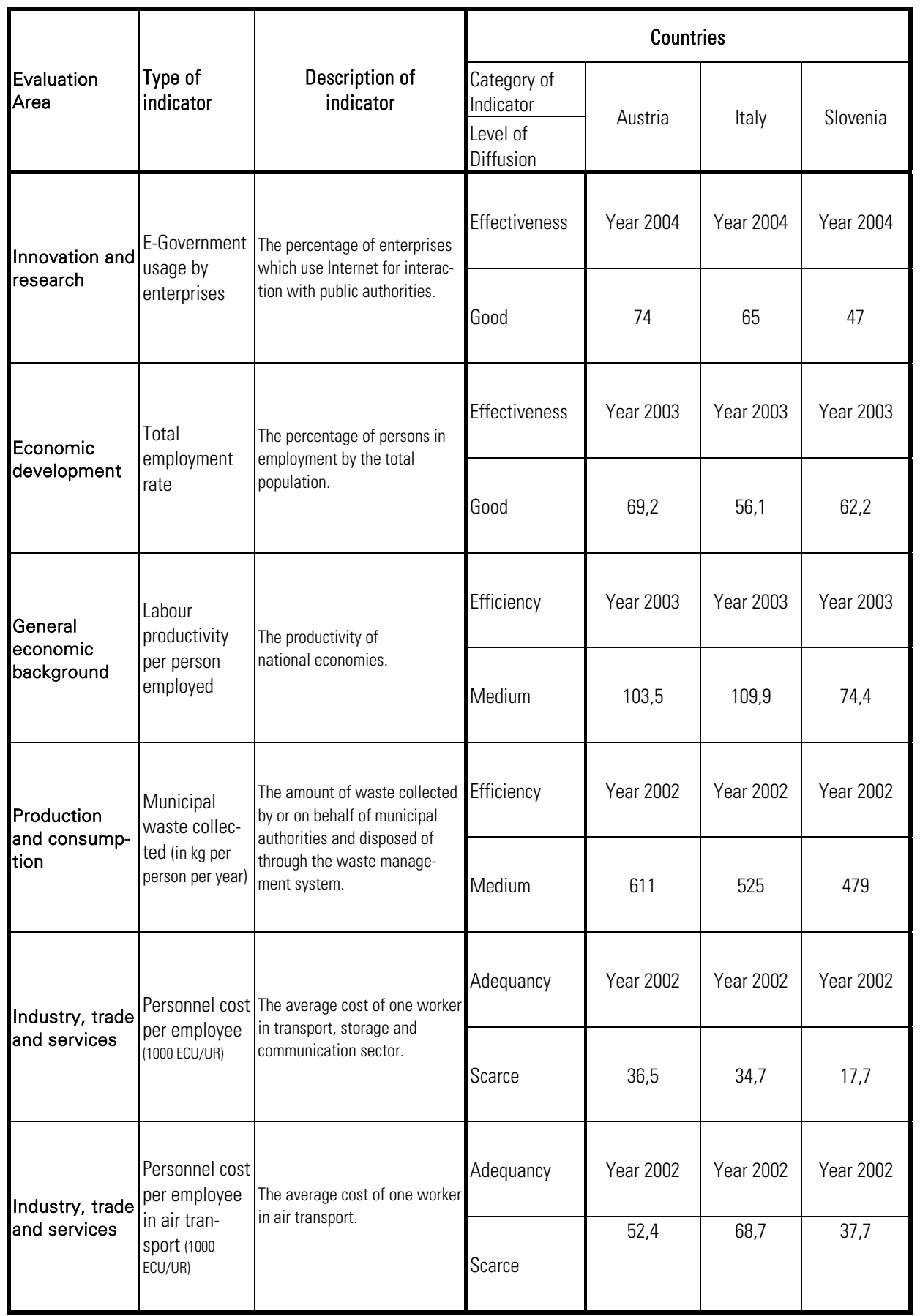

Source: www.eurostat.com 
Laura Tampieri

Performance Evaluation Indexes in Public Administration

Table 4: The relationship between indicator types and level of diffusion

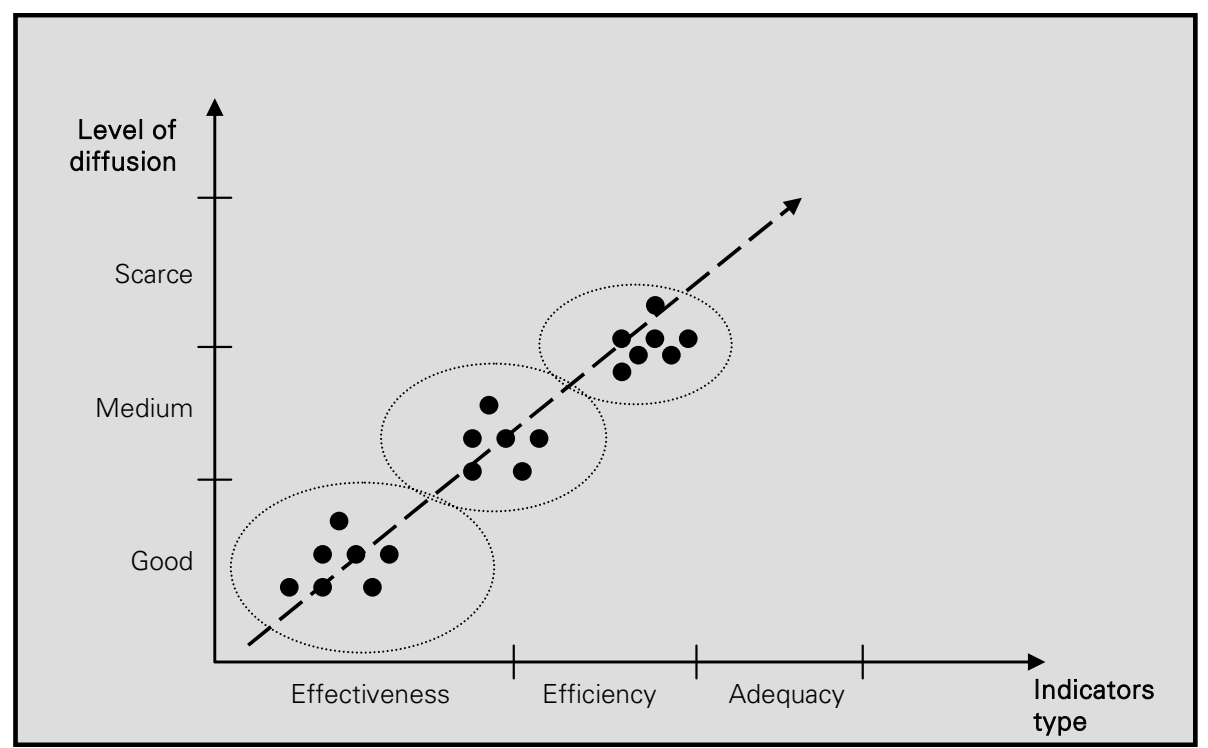

Inside effectiveness category (Table 5) we can consider the e-government usage by enterprises. This indicator shows the percentage of enterprises using Internet to interact with public authorities (i.e. having used Internet for one or more of the following targets: obtaining information, downloading forms, filling-in web-forms, full electronic case handling), while the usage rate is calculated by dividing the number of persons aged 15 to 64 in use by the total population of the same age group. The indicator is based on the EU Labour Force Survey.

Table 5: Effectiveness indicators set proposed by Eurostat

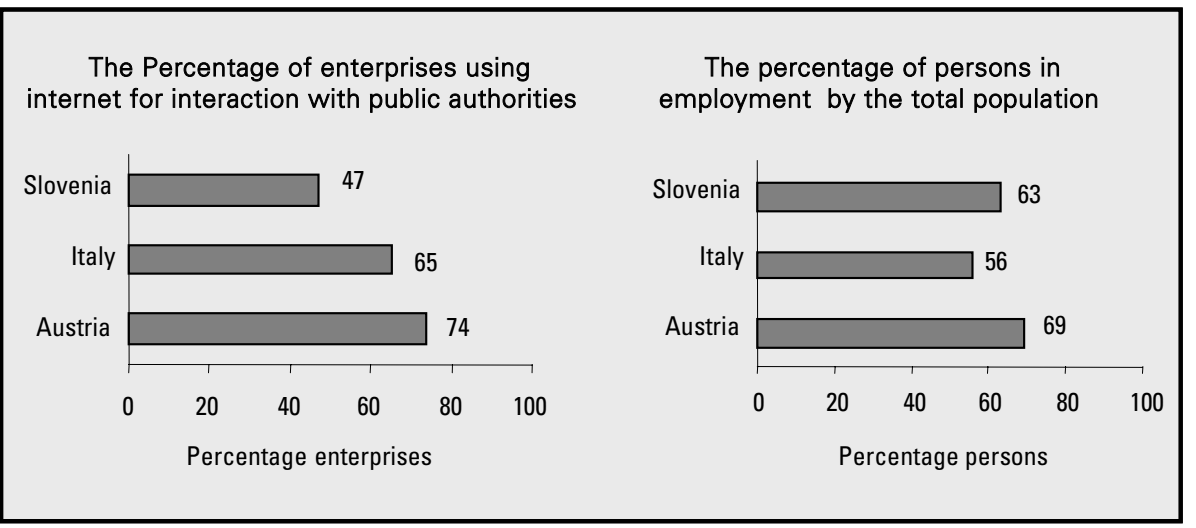


This survey covers the entire population living in private households and excludes those in collective households such as boarding houses, halls of residence and hospitals. Employed population consists of persons who during the reference week did any work for pay or profit for at least one hour, or were not working but had jobs from which they were temporarily absent.

The second type of indicator is efficiency (Table 6). In this class the labour productivity per person employed is included, indicator expressed by GDP in purchasing power standards (PPS) per person employed relative to EU-25 (100). This indicator is intended to give an overall impression of the productivity of national economies expressed in relation with the European Union (EU25 ) average. If the index of a country is higher than 100 , this country's level of GDP per person employed is higher than the EU average and vice versa.

Table 6: Efficiency indicators set proposed by Eurostat

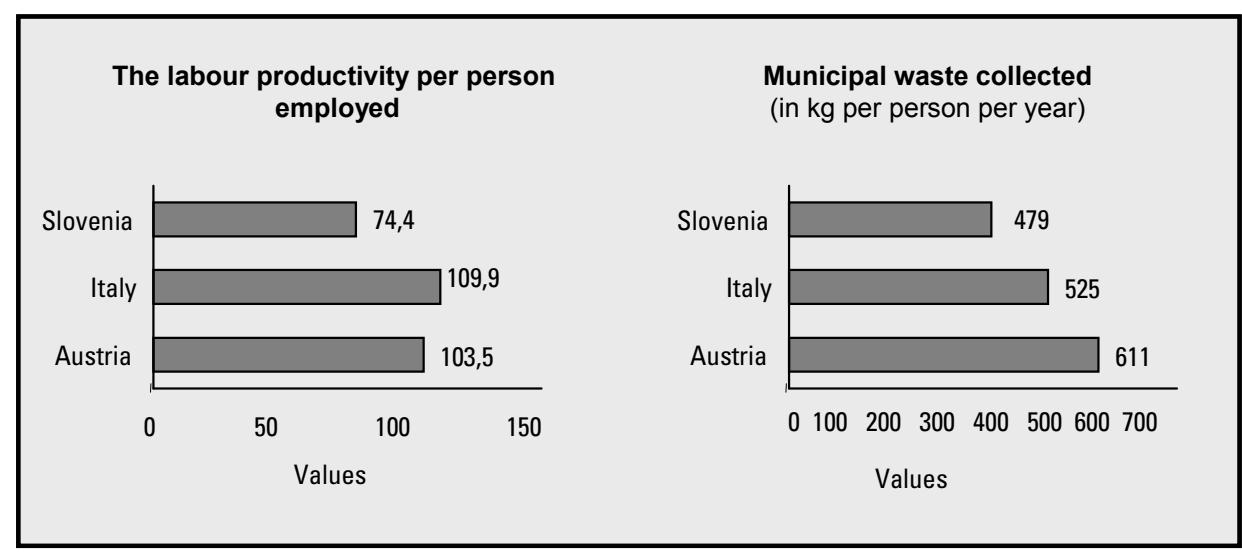

Another example of efficiency indicator is municipal waste collected (the quantity is expressed in $\mathrm{kg}$ pro capita per year).This indicator presents the amount of waste collected by or on behalf of municipal authorities and disposed of by the waste management system. The bulk of this waste stream is from households, though "similar" wastes from sources such as commerce, offices and public institutions are included.

As regards adequacy class we can consider the personnel cost per employee (the quantity is expressed in $1000 \mathrm{ECU} / \mathrm{EUR}$ ) which means the average cost of one worker in transport sector. On one hand, per head staff high expenditure is a sign of a high labour cost. On the other hand, it can denote a high staff qualification and hence be a synonym for a high productivity. In particular we can take into consideration the personnel cost per employee in air 
Laura Tampieri

\section{Performance Evaluation Indexes in Public Administration}

transport which measures the average cost of one worker in the considered transport service (Table 7).

Table 7: Adequacy indicators set proposed by Eurostat

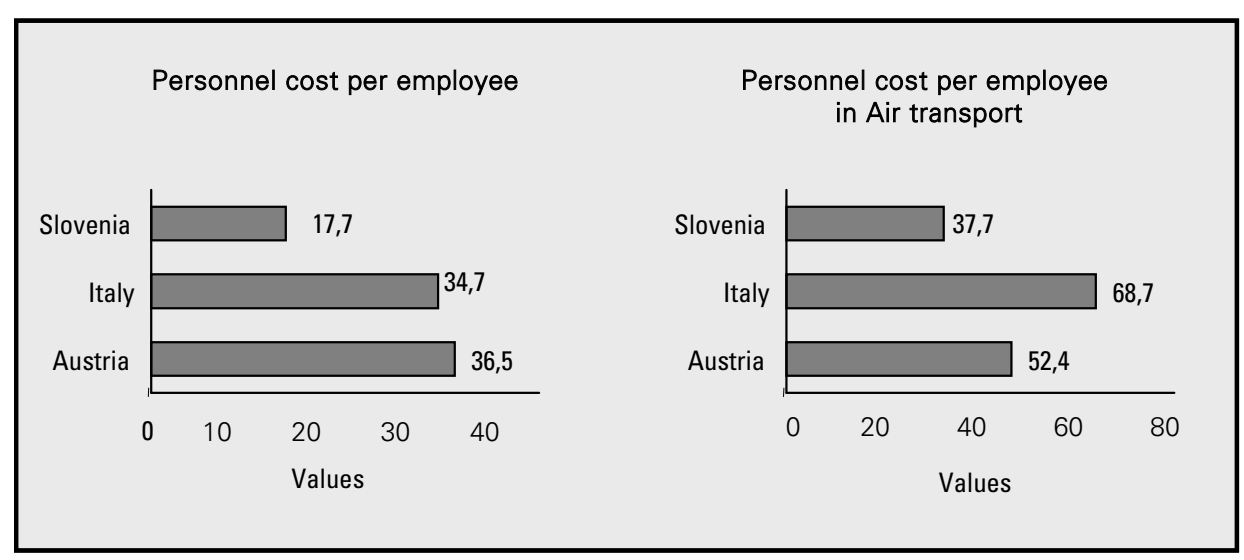

The frequency of effectiveness indexes among key indicators proposed by Eurostat means that they are very diffused in the examined public administrations. Efficiency indicators are less spread because they are linked mainly to financial resources. Those referring to adequacy are less used because they are connected to quality and rating concepts.

\section{Conclusion}

Several studies show that there is a convergence in approach taken by different governments: the measures include budgetary reductions, deregulation, new technologies, new management methods, new tools and criteria for evaluation, decentralisation, devolution, flexibility in personal matters, service quality, customer orientation and privatisation (Pollit, 1993, Wollmann, 2003).

Thus performance evaluation has become a key element in the public sector reform of many countries. The activities and achievements of public organizations can be divided into a variety of categories linked to economy, efficiency, effectiveness, adequacy concepts.

These indicators typically fall into three measures: input of services (such as expenditure, staffing and equipment); output of services (such as quantity and quality, which in turn can be divided into speed and accessibility of service delivery), and outcomes relating to whether formal objectives are achieved (e.g. whether school pupils pass exams). 
Furthermore, some of the activities and achievements can be combined to form important ratios (e.g. effectiveness, efficiency and adequacy); these performance indicators are at the heart of a monitoring system and they define the data to be collected to measure progress and enable actual results achieved over time to be compared with planned results. Thus, they are a management tool for making performance decisions about program strategies and activities.

The elements of the performance measurement system developed in the examined countries are studied in consideration of their spread and level of applicative difficulty in public administrations. So focusing on inner performance indicators, the frequency of effectiveness in European public administrations is explained by the facility of locate them in the set proposed by Eurostat. This is due to the fact that effectiveness indicators are easier to apply rather than those of efficiency and adequacy.

Efficiency and adequacy indexes are less spread because they are difficult to implement in organizations. In particular efficiency is placed in midway between effectiveness and adequacy indexes because of the consideration of resources and results. As regards adequacy, the difficulty of implementation is tied to the adoption of strategies, plans and programs requiring the definition of adequate resources to attain objectives.

Laura Tampieri is PhD Student in Economics and Management of Public Administrations course - Salerno University. She won a grant from Forli Faculty of Economics on the subject "Self Local Government System in Slovenia" in the Faculty of Administration - Ljubljana University. She takes part in some Bologna University projects in SME creation in Transition Countries. She collaborates with Prof. Massimo Bianchi in teaching courses of Business Management, Logistics, Human Resource Management in the Faculty of Economics - Forli.

\section{References}

- $\quad$ Andrews Rhys, Boyne, G. A., Law, J. and Walker, R.M. (2003): Myths, measures and modernization: a comparison of local authority performance in England and Wales in Local Government studies, vol.29, n.4

- Anselmi, L. (1998): Unità e diversità delle problematiche aziendali del settore pubblico italiano, in M. Bianchi (a cura di) La pubblica amministrazione di fronte all'Europa, II Ponte Vecchio ed.

- Anselmi, L., (2003): Percorsi aziendali per le amministrazioni pubbliche, Giappichelli ed. 


\section{Laura Tampieri \\ Performance Evaluation Indexes in Public Administration}

- Anselmi, L., Bianchi, M., Fiori, G., Giovanelli, L., Mele, R., Merli, M.Z., Mussari, R., Pavan, A., Saita, M., (2004): L'innovazione nei servizi delle pubbliche amministrazioni per la competitività delle PMI, Giuffrè ed.

- Bianchi, M. (2001): Il sistema organizzativo e le funzioni aziendali, Giappichelli ed.

- Bianchi, M. (2002): Un test per valutare i sistemi di controllo, valutazione e incentivazione delle performance negli Enti Locali, in Azienditalia n. 10

- Bianchi, M. (2004): Information Technologies and services tracking in the organizational development of Public Administration. The cases of P.A.Next and LEDA. Relazione al Symposium Internazionale, Information, Knowledge and Management. Re-assessing the role of ICTs in public and private organizations, Scuola Superiore della Pubblica Amministrazione, Bologna

- Boccia, F. (2005): II ruolo dell'azienda pubblica nel nuovo sistema europeo di programmazione delle politiche di sviluppo, in Azienda Pubblica n.2

- Bouckaert, G., Van de Walle, S. (2003): Comparing Measures of Citizen Trust and User Satisfaction as Indicators of "Good Governance": Difficulties in Linking Trust and Satisfaction indicators, in International Review of Administrative Sciences n.3

- Boland, T., Fowler, A.(2000): A system perspective of performance management in public sector organizations, in International Journal of Public sector management, vol.13, n.5

- Boyle, R., Lemaire, D. (1999): Building Effective evaluation capacity: lessons from practice, Transaction Publisher New Brunswick

- Boyne, G.A. (2002): Concepts and Indicators of Local Authority Performance: An evaluation of the Statutory Framework in England and Wales, in Public Money\&Management

- Boyne, G.A., Farrell, C., Law, J., Powel, M., Walker, R.M.(2003): Evaluating public management reforms. Principles and practice, Open University Press, Philadelphia.

- Carter, N. (1988): Measuring Government Performance, in Political Quarterly 59, n. 3

- Cavalluzzo, K.S. (2002): Competition, fee-for-service requirements, and government performance: evidence on the Federal Reserve, in Journal of Accounting and Public Policy

- Connolly, T., Conlon, E., Deutsch, S.(1980): Organizational Effectiveness: a multiple constituency approach, in Academy of Management Review, 5 , pag. 211-17

- Del Bello, A.(2003): L'ascesa del concetto di sostenibilità negli Enti pubblici locali: il progetto "Agenda 21" del comune e della provincia di Ferrara, in Vagnoni E.(a cura di) Azienda, Economia, Impresa ed Università, Este

- Devjak, S., Peček, B. (2001): Development of the system of performance indicators and increase of the efficiency of municipalities, in M. Bianchi (a cura di) Enti Pubblici e competitività, II Ponte Vecchio ed.

- Eccles, R.G.(1991): The Performance Measurement Manifesto, Harvard Business Review, January-February 


\section{Performance Evaluation Indexes in Public Administration}

- Farneti, G., Mazzara, L., Savioli, G. (1996): Il sistema degli indicatori dell'Ente Locale, Giappichelli ed.

- Farneti, G. (2002): Gestione e contabilità dell'Ente Locale: il bilancio, il PEG, la nuova contabilità economica, il controllo di gestione, il controllo strategico, il nucleo di valutazione, il rendiconto, I'euro, Maggioli ed.

- Farneti, G., Pozzoli, S. (2005): Principi e sistemi contabili negli Enti Locali: il panorama internazionale, le prospettive in Italia, FrancoAngeli ed.

- Flynn, A., Gray, A., Jenkins, W., Rutherford, B.(1988): Making Indicators perform, in Public Money and Management 8, n. 4

- Grandori, A.(1999): Organizzazione e comportamento economico, II Mulino

- Gunn, L. (1988): Public Management : a Third Approach? in Public Money and Management 8, n.2

- Harrinvirta, O.M. (2000): Strategies of Public Sector Reform in the OECD Countries: A comparison, Finnish Society of Science and Letters and Finnish Academy of Science and Letters, Finland

- Kaplan, R.S., Norton D.P.( 1992): The balance Scorecard - Measures that Drive Performance, Harvard Business Review

- Jackson, P. (1988): The management of performance in the Public Sector, in Public Money and Management, winter 11-15

- Longo, F. (2004): Riforme istituzionali e sviluppo manageriale delle PA: quali driver di cambiamento?, in Economia \& Management

- Lüder, K.(1988): Governmental accounting in West European countries: with special reference to the Federal Republic of Germany, in Chan J., Jones R., Governmental accouonting and auditing. International comparisons, Routledge, London

- Maas, J. (1995): The management of ethics and conduct in the public service, Ministry of the Interior, the Netherlands

- Mayne, J., Zapico, E. (1977): Monitoring Performance in the Public Sector, Transaction Publisher New Brunswick (USA) and London (UK)

- Morri, G., Foschi, S., Tagliabue, S. (2001): II Piano Esecutivo di Gestione: principi, metodologie e procedure per la direzione dell'Ente Locale, Maggioli ed.

- Mussari, R.(1998): Il New Public Management e l'orientamento ai valori economici, in M. Bianchi (a cura di), La pubblica amministrazione di fronte all'Europa, II Ponte Vecchio ed.

- OECD (1994): Performance Management in Government: Performance Measurement and Results-Oriented Management, Occasional Papers Public Management n. 3, OECD Paris

- OECD (1997): In search of Results: Performance Management Practices OECD Paris

- $\quad$ OGC (2002): How to manage performance, Format publishing 


\section{Laura Tampieri \\ Performance Evaluation Indexes in Public Administration}

- Pavan, A. (2001): L'amministrazione economica delle aziende, Giuffrè ed.

- Peess, R. (2001): Controlling within the Scope of New Management System: Introduction to the Public Administration in Germany

- Pollit, C. (1993): Managerialism and the Public Services, Blackwell, Oxford

- Pozzoli,S. (2002): Il controllo direzionale negli Enti Locali, FrancoAngeli ed.,

- Reck, J. L.(2001): The usefulness of financial and non financial performance information in resource allocation decisions, in Journal of Accounting and Public Policy

- Rosen, E.D. (1993): Improving Public Sector productivity: concepts and practice, Sage Publications

- Sanderson, I. (2001): Performance management, evaluation and learning in "modern" local government, in Public Administration

- Scherrer, W.(2004): Strategical Informations about a business location on the web: Investors' needs and a local Authority's offer in Salzburg, in G. Traversa, M. Potente (a cura di), L'Orchestra burocratica. Modelli, metodi e strumenti per la E-Administration, Presidenza del Consiglio dei Ministri, Scuola Superiore Pubblica Amministrazione, Roma

- Tomkins, C.(1987): Achieving Economy, Efficiency and Effectiveness in the Public Sector, London, Kogan Page

- Vitali, P.M. (2001): I sistemi di misurazione economico-finanziaria nelle Università italiane: problemi e prospettive, Cedam ed.

- Wollmann, H.(2003): Evaluation in Public-Sector Reform: Concepts and Practice in International Perspective, Edward Elgar, USA 


\section{POVZETEK}

\section{Vrednotenje ekonomskih kazalnikov $v$ javni upravi}

Pregled njihove dejanske uporabe

Članek obravnava pristop k uporabi sistemov ekonomskih kazalnikov $v$ javni upravi. Reforme $v$ javnem sektorju se usmerjajo iz klasične zakonitosti delovanja na oblikovanje politike in njeno vrednotenje kot osnovni element upravljanja za rezultate, kar je postalo eden izmed mejnikov javnega sektorja.

Večina mednarodnih študij posledično obravnava načelo dobrega upravljanja ne glede na instančno in sodno kontrolo, pač pa glede na kazalnike uspešnosti, učinkovitosti in primernosti. Uporabljen pristop se ukvarja z razlikami med omenjenimi indikatorji in izhaja iz težavnostnega nivoja njihove uporabnosti pri implementaciji v javni upravi. Bolj kot definicijo meril, ki izraža nivo zadovoljstva pri zadovoljitvi splošnih potreb, mora javna uprava sprejeti sistem, ki vsebuje indikatorje kvalitete in stroškov pri zagotavljanju storitev in dobrin. Z njimi lahko opravljamo nadzor nad sposobnostjo organizacije, da zadovolji potrebe strank glede na porabljena sredstva $v$ upravljavskem procesu. Raziskava zato primerja sisteme indikatorjev s področja evropske javne uprave glede na njihovo aplikativno sposobnost $v$ povezavi z osnovnimi strukturami uspešnosti, učinkovitosti in primernosti. Indikatorji morajo namreč zadovoljiti dve osnovni zahtevi: uporabljeni so lahko kot instrument interne kontrole, prav tako pa omogočajo državljanom, da opravljajo kontrolo nad proizvodi javne uprave. $\mathrm{Na}$ ta način lahko državljani, menedžerji in investitorji ovrednotijo javne aktivnosti in prek analize indikatorjev naredijo primerjavo med različnimi državnimi in lokalnimi javnimi upravami.

$\checkmark$ prispevku je narejena primerjava avstrijskih, italijanskih in slovenskih kazalnikov uspešnosti, $s$ poudarkom na razmerju med indikatorji in njihovo stopnjo uvrstitve med državne nadzorne mehanizme. Prispevek še posebej poudarja povezavo med težavnostjo aplikacije indeksov in nivojem razpršitve $v$ javni upravi. Osredotoča se na notranje kazalnike, pogostost uporabe kazalnika uspešnosti v evropskih javnih 
Laura Tampieri

Performance Evaluation Indexes in Public Administration

upravah pa je uporabljena zaradi lahkega dostopa iz predloga Eurostata. Cilj je povezati ekonomske kazalnike $z$ njihovo razširjenostjo $v$ javni upravi. Indikatorja učinkovitosti in primernosti sta manj razširjena za razliko od indikatorja uspešnosti, ker ju je težko implementirati v organizacijah. Kazalniki, ki se nanašajo na uspešnost so zelo razširjeni, ker uporabljajo razmerje med rezultati in cilji, indikator učinkovitosti je lahko izražen $z$ razmerjem med rezultati in sredstvi, njihov nivo razširjenosti je srednji. Naslednji indikator je primernost, ki je manj razširjen zaradi tesno povezanega razmerja z zapletenimi in nedefiniranimi koncepti kvalitete in etike. 